\title{
Label-free vibrational imaging of different $A \beta$ plaque types in Alzheimer's disease reveals sequential events in plaque development
}

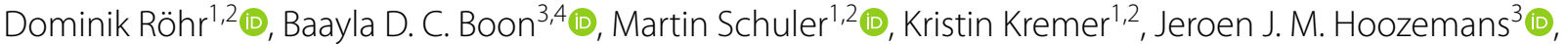 \\ Femke H. Bouwman ${ }^{4}$ (D) Samir F. El-Mashtoly ${ }^{1,2}$, Andreas Nabers ${ }^{1,2}$ (D) Frederik Großerueschkamp ${ }^{1,2}$ (D), \\ Annemieke J. M. Rozemuller ${ }^{3}$ and Klaus Gerwert ${ }^{1,2^{*}}$ (D)
}

\begin{abstract}
The neuropathology of Alzheimer's disease (AD) is characterized by hyperphosphorylated tau neurofibrillary tangles (NFTs) and amyloid-beta (AB) plaques. A $\beta$ plaques are hypothesized to follow a development sequence starting with diffuse plaques, which evolve into more compact plaques and finally mature into the classic cored plaque type. A better molecular understanding of $A \beta$ pathology is crucial, as the role of $A \beta$ plaques in $A D$ pathogenesis is under debate. Here, we studied the deposition and fibrillation of $A \beta$ in different plaque types with label-free infrared and Raman imaging. Fourier-transform infrared (FTIR) and Raman imaging was performed on native snap-frozen brain tissue sections from AD cases and non-demented control cases. Subsequently, the scanned tissue was stained against $A \beta$ and annotated for the different plaque types by an AD neuropathology expert. In total, 160 plaques (68 diffuse, 32 compact, and 60 classic cored plaques) were imaged with FTIR and the results of selected plaques were verified with Raman imaging. In diffuse plaques, we detect evidence of short antiparallel $\beta$-sheets, suggesting the presence of $A \beta$ oligomers. A $\beta$ fibrillation significantly increases alongside the proposed plaque development sequence. In classic cored plaques, we spatially resolve cores containing predominantly large parallel $\beta$-sheets, indicating A $\beta$ fibrils. Combining label-free vibrational imaging and immunohistochemistry on brain tissue samples of AD and non-demented cases provides novel insight into the spatial distribution of the $A \beta$ conformations in different plaque types. This way, we reconstruct the development process of $A \beta$ plaques in human brain tissue, provide insight into $A \beta$ fibrillation in the brain, and support the plaque development hypothesis.
\end{abstract}

Keywords: Alzheimer's disease, Amyloid plaque, Human, Amyloid-beta, Oligomer, Fibril, Microspectroscopy, FTIR, Infrared, Raman, Imaging

\section{Introduction}

Alzheimer's disease (AD) is the most common neurodegenerative disease and is pathologically characterized by hyperphosphorylated tau neurofibrillary tangles (NFT) and amyloid-beta $(A \beta)$ plaques. $A \beta$ originates from the

*Correspondence: klaus.gerwert@rub.de

1 Division of Biospectroscopy, Center for Protein Diagnostics (PRODI), Ruhr University Bochum, Bochum, Germany

Full list of author information is available at the end of the article cleavage of the amyloid precursor protein (APP) and is secreted to the extracellular space. The most accepted hypothesis for $\mathrm{AD}$ pathogenesis is the amyloid cascade hypothesis $[32,66]$. According to this hypothesis, $A \beta$ aggregates in the neuropil as plaques, due to an imbalance of $A \beta$ production and clearance. The $A \beta$ monomers misfold and form $\beta$-sheet-rich oligomers, which then form protofibrils that stack into highly organized amyloid fibrils $[38,50]$. The aggregation of $A \beta$ causes synaptic stress and induces an inflammatory response. 
Simultaneously, synaptic and neuronal injury leads to the hyperphosphorylation of tau, which aggregates within neurons as NFTs that finally cause neuronal death. As the disease spreads and progresses, there is extensive neuronal death throughout the brain, which ultimately leads to dementia. The amyloid cascade hypothesis is currently under debate. While it is proposed that $A \beta$ is the initial trigger of pathological processes, NFTs are considered to be the progressive force of the disease [55]. The discussion is fueled by several failed clinical studies of $\mathrm{A} \beta$-targeting antibodies, as well as encouraging results of most recent anti-A $\beta$ drug studies [77, 12, 67].

$A \beta$ plaques show different morphologies. Here, we consider (i) the diffuse type, (ii) the compact (or primitive) type, and (iii) the classic cored type [76]. It is proposed that these different morphologies represent the progressive stages of $A \beta$ fibrillation [7, 34, 62, 75]. Plaque formation is proposed to start as diffuse amorphous structures that mainly consist of aggregated $A \beta$ oligomers and protofibrils. Then, with the progression of $A \beta$ fibrillation, the plaque shows an increasingly compact morphology with a more clearly defined outline. An inflammatory response, driven mainly by microglia, is strongly associated with the early stages of $A \beta$ plaque formation and even considered to drive the continuing build-up of amyloid fibrils and the accompanied neurotoxic effects [48, $61,74]$. The final fibrillation stage is reached when $A \beta$ is condensed to a core that contains mostly A $\beta$ fibrils.

Here, we applied Fourier transform infrared (FTIR) and Raman imaging to snap-frozen thin sections of human brain tissue. These label-free methods are much less invasive towards the sample than staining methods because the tissue is examined without chemical alterations [30]. The vibrational microspectroscopy approach provides spatially resolved spectra that reflect the biochemical fingerprint of analyzed samples, including the protein secondary structure $[21,26,31]$. Raman is a complementary spectroscopic technique to FTIR and is used here to verify the FTIR results. The major constituents of brain tissue are proteins and lipids [53]. The secondary structure of proteins can be determined by analyzing the Amide I absorbance band $(\mathrm{C}=\mathrm{O}$ stretching vibration of the protein backbone). The Amide I absorbance band is indicative for the secondary structure. It consist of several bands, each associated with distinct secondary structures $[28,29,37]$. The position of the main $\beta$-sheet-band around $1630 \mathrm{~cm}^{-1}$ shifts towards lower wavenumbers, when the strands become arranged in parallel $\beta$-sheets $[9,47,78]$. Accordingly, amyloid fibrils often absorb at a lower wavenumber than native $\beta$-sheet proteins [83]. For instance, oligomeric $A \beta$ with typically antiparallel $\beta$-sheet structure absorbs around $1630 \mathrm{~cm}^{-1}$, whereas a shift to lower wavenumbers has been reported for $A ß$ fibrils [5,
$41,54,63,64]$. Furthermore, antiparallel $\beta$-sheets display a characteristic band around $1693 \mathrm{~cm}^{-1}$. This band is not observed in $A \beta$ fibrils with predominantly parallel $\beta$-sheets $[8,10]$. Here, the accumulation of $\beta$-sheet-rich $\mathrm{A} \beta$ oligomers and fibrils in plaques is studied, analyzing the Amide I band. Apart from that, lipids constitute about $40 \%$ of the gray matter dry weight [56] and show characteristic absorbance bands as well. The fatty acids in lipids consist mostly of methylene and methyl $\left(\mathrm{CH}_{2}\right.$ and $\mathrm{CH}_{3}$ groups, which also occur in protein side chains) that generate stretching vibration bands in the region 3000$2800 \mathrm{~cm}^{-1}$. The head groups of most phospholipids, which make up $70 \%$ of the lipid content, contain ester groups that generate the lipid-associated band (ester $\mathrm{C}=\mathrm{O}$ stretching vibration) around $1738 \mathrm{~cm}^{-1}[18,43]$.

In this study, the progression of $A \beta$ fibrillation, alongside the proposed development sequence of $A \beta$ plaques (diffuse, compact, classic cored) in AD is studied with spatial and molecular resolution, using label-free imaging. Post-mortem sections from fresh-frozen brain tissue were analyzed by FTIR and Raman imaging without chemical tissue treatment to stay as close to the brain's conditions as possible. Particularly, the secondary structure-sensitive Amide I band was analyzed spatially resolved in different $A \beta$ plaque types. Plaques in the analyzed region were subsequently confirmed by anti-A $\beta$ immunohistochemistry $(\mathrm{A} \beta-\mathrm{IHC})$ on the same tissue section. We observed increased $A \beta$ fibril contents alongside the ascending plaque stages. The spectral image analysis provides insight into the spatial distribution of $A \beta$ structure in different plaque types, contributing evidence for the current hypotheses on plaque development.

\section{Materials and methods}

\section{Post-mortem human brain tissue}

Post-mortem brain tissue was selected from the Netherlands Brain Bank (the NBB; Amsterdam, The Netherlands). Donors or their next of kin signed informed consent for the usage of brain tissue and clinical information for research purposes. The Institutional Review Board and Medical Ethical Board from the Vrije University Medical Center approved the procedures of the NBB. Neuropathological diagnosis was performed (by A.J.M.R) and was based on multiple (immuno)histochemical stainings of diversified brain regions according to the standard operating procedures of the NBB and BrainNet Europe consortium. AD cases $(n=5)$ were selected when clinical and neuropathological information fulfilled the criteria of the National Institute on Aging-Alzheimer's Association (NIA-AA) for $\mathrm{AD}$ and no other neurodegenerative or psychiatric disease was present [51]. Two additional AD cases with the vascular type were included-also referred to as CAA-Type 1 . These cases do not fit the typical 
NIA-AA criteria, since amyloid and tau depositions are vascular related. Controls were selected when no cognitive decline was reported during life and AD pathology was absent or 'low' (Additional file 1: Table 1). Snap-frozen tissue of the superior parietal lobule (LPS) was used, as this neocortical area shows the plaque types of interest. Sections $(20 \mu \mathrm{m})$ were mounted on $\mathrm{CaF}_{2}$ slides for vibrational imaging and subsequent $\mathrm{A} \beta-\mathrm{IHC}$. Tissue sections were stored at $-80{ }^{\circ} \mathrm{C}$ in-between experiments in order to minimize sample degradation [46].

\section{FTIR imaging}

FTIR was conducted with a Cary 670 spectrometer (Agilent Technologies), coupled to a Cary 620 microscope (Agilent Technologies) in transmission mode. The microscope features a $128 \times 128$-element focal plane array detector and a $15 \times(0.62 \mathrm{NA})$ objective. In high magnification mode $(5 \times$ optical increase), the instrument yields a nominal pixel size of $1.1 \mu \mathrm{m}$. Each $128 \times 128$-element data acquisition provided a field of view (FOV) of approximately $141 \times 141 \mu \mathrm{m}$. interferograms were obtained as a mean of 128 scans. Using Blackman-Harris-4-term apodisation, power phase correction and zero-filling factor 2 for Fourier-transformation, the resulting spectral range was $3700-948 \mathrm{~cm}^{-1}$ at a spectral sampling interval of $1.9 \mathrm{~cm}^{-1}$. For background correction, a clean area of each $\mathrm{CaF}_{2}$ slide was measured (1024 scans) and subsequently subtracted from sample measurements. The software Resolutions Pro 5.3 was used for image acquisition. The instruments and the sample cavity were continuously purged with dry air to reduce atmospheric water vapor contribution and to maintain the samples in a conserving dry state. We checked for spectral alterations that may have been caused by prolonged exposure to the dry air environment during the experiments. None of the bands used here for plaque analysis showed noteworthy alterations (Additional file 1: Fig. 1).

\section{Immunohistochemical staining}

Following spectral measurements, the sample was placed into a container filled with argon at a temperature of $36{ }^{\circ} \mathrm{C}$ for one hour to increase the tissue adherence whilst maintaining dry conditions. The sample was fixated in ethanol for $10 \mathrm{~min}$, and dipped in a gelatin solution $(0.3 \%$ in $50 \mathrm{mM}$ Tris-HCL buffer) to further increase tissue adherence. After washing $(3 \times 5 \mathrm{~min}$ in PBS (Thermo Fisher)), the sample was incubated with the primary antibody mouse-anti-A $\beta$ directed against aa1-16 (clone IC16) in antibody diluent (Agilent Dako) for one hour. After washing, the sample was incubated with Envision (Agilent $D a k o$ ) for $1 \mathrm{~h}$ and washed. Color development was done using DAB (Agilent Dako). The section was dehydrated in an ethanol series (70-96-100\%), mounted with Euporal
(Roth) and coverslipped. The stained sample was subsequently imaged with an Olympus BX61VS slide scanner, using the UPlanSApo $20 \times 0.75 \mathrm{NA}$ objective (Olympus). The exemplary classic cored plaque appears to have a hollow core in the A $\beta$-IHC image (Fig. $2 \mathrm{~A}_{4}$ ). This phenomenon was described before [65] and may derive from incomplete antibody penetration into the plaque core during the $\mathrm{A} \beta-\mathrm{IHC}$ staining procedure. Another classic cored plaque with a homogeneously stained core exhibits similar distributions of ( $\beta$-sheet) protein (Additional file 1: Fig. 2).

\section{Image alignment}

In order to link spectral data with $\mathrm{A} \beta$-IHC images, both modalities were precisely overlaid. We used a homemade software (written in Matlab) to determine an affine 2D transformation that warps the A $\beta$-IHC image onto the coordinate system of the vibrational images, based on reference coordinates given by the user. The quality of the overlay was visually verified, based on tissue morphology. Subsequently, a region of interest (ROI) within the spectral coordinates was chosen for each plaque. The ROI of the spectral image and the corresponding region of the $\mathrm{A} \beta$-IHC image were cut out and saved for further analysis. Exemplary cutouts are shown in Fig. 1.

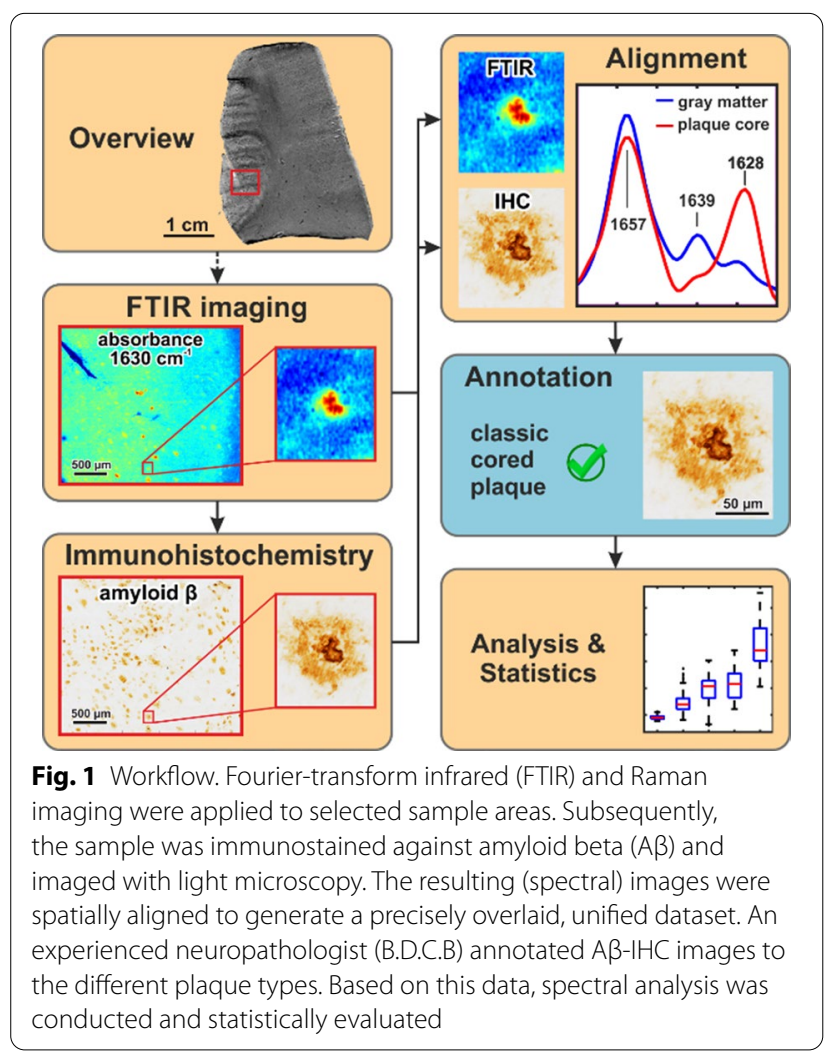




\section{Plaque annotation}

The cutouts of the $\mathrm{A} \beta$-IHC image, containing one plaque each, were transferred to an $\mathrm{AD}$ neuropathology expert (B.D.C.B) who has extensive experience with plaque morphologies. No further information was given; the expert was blinded regarding case numbers and disease stages. The expert assigned each plaque to one of the following classes: (1) diffuse plaque, (2) compact plaque, (3) classic cored plaque, (4) miscellaneous, (5) no assignment possible. In this study, only plaques of the diffuse, compact and classic cored type were used.

\section{FTIR spectral data preparation}

Spectra, which were not suitable for analysis, were determined by their noise level $(\mathrm{SNR}<100)$. In addition, spectra with strong scattering contribution $\left(\mathrm{A}_{\text {silent region }}>\mathrm{A}_{1655} / 2\right)$ were excluded. Scattering appears as apparent absorbance in the so-called "silent region" (e.g. 2300-1800 $\mathrm{cm}^{-1}$ ), where biological samples usually display no absorbance (Additional file 1: Fig. 3). Thus, a small fraction of spectra was excluded from analysis in order to prevent statistical distortions by outlier spectra. All remaining spectra were subjected to Mie scattering correction, based on extended multiplicative signal correction (EMSC) $[42,70]$. Additional file 1: Fig. 3 presents exemplary plaque spectra before and after the application of EMSC.

In order to identify spectra within a hypercuboid that correspond to a plaque (more precisely "A $\beta$ positive area"); a binary mask was generated from the A $\beta$-IHC image cutouts (Additional file 1: Fig. 4), using Otsu's method (Matlab Image Processing Toolbox) [57]. The henceforth-called plaque spectrum is the arithmetic mean of all pixel-spectra within this mask. Another mask was generated that describes a ring-shape with a radial thickness of $100 \mu \mathrm{m}$, surrounding the plaque, excluding A $\beta$-positive pixel, which were again detected by using Otsu's method. The arithmetic mean of the spectra corresponding to the latter mask is henceforth called surrounding spectrum.

\section{FTIR spectral data analysis}

For the structural analysis of each classic cored plaque, the respective spectral image cutout was separated using hierarchical cluster analysis (HCA) (Matlab, Statistics toolbox). Spectra were thereby grouped into 10 subgroups based on spectral similarity. The subgroups belonging to the core or the corona were each selected by visual comparison to the corresponding $\mathrm{A} \beta$-IHC image and merged, if applicable. The arithmetic means of spectra belonging to the core were used in further analysis and are being referred to as core spectra of the inner core. Difference spectra were calculated between plaque spectra and surrounding spectra. For the analysis of the Amide region, a linear baseline was subtracted from the spectra within the range $1800-1480 \mathrm{~cm}^{-1}$. Whereas, for the detailed investigation of the band around $1630 \mathrm{~cm}^{-1}$, a linear baseline was subtracted from the Amide I bands within the range $1690-1610 \mathrm{~cm}^{-1}$. The bands were subsequently area-normalized in the range $1690-1610 \mathrm{~cm}^{-1}$ and subtracted from each other. Arithmetic means of all difference spectra from a respective plaque-type were calculated and interpolated with a spline for display. Second derivatives of spectra were calculated, using a Savitzki-Golay filter with a third-degree polynomial and a frame size of five (Matlab, Signal Processing toolbox).

\section{FTIR band assignment and interpretation}

We determined spectroscopic ratios between FTIR absorbance bands that correspond to vibrational modes of the protein backbone, $\mathrm{CH}_{2}$, and $\mathrm{CH}_{3}$ groups (Additional file 1: Table 2). The protein accumulation is quantified by the Amide II peak $\left(\mathrm{A}_{1545}, \mathrm{~N}-\mathrm{H}\right.$ bending vibration) of the protein backbone vibration [45], in proportion to the absorbance in the $\mathrm{CH}$-stretching region, as proxy for total absorbance from lipids and proteins. The $\beta$-sheet levels are quantified by the ratio $\mathrm{A}_{1630} / \mathrm{A}_{1655}$ of respective bands representing $\beta$-sheets and non- $\beta$-sheet secondary structures. The band positions were derived from second derivatives. The band around $1655 \mathrm{~cm}^{-1}$ is commonly associated with $\alpha$-helical proteins, but as e.g. unordered structures may also contribute to the band, we use the term non- $\beta$-sheets here.

\section{Statistical analysis}

The spectroscopic ratios and band height differences in second derivatives were used for statistical analysis. Additional to the A $\beta$ plaques, 208 randomly selected small (approx. $100 \times 100 \mu \mathrm{m}), A \beta$-negative areas from the gray matter of non-demented cases constituted the control group. Furthermore, core spectra were included as a separate group. In between each group, p-values were calculated alongside the proposed development sequence (Matlab, Statistics toolbox), according to Student's t-test [71]. The confidence levels were determined according to p-values $<0.05\left(^{*}\right),<0.01\left(^{* *}\right)$ and $\left.<0.001{ }^{(* * *)}\right)$. The correlation between the ratios was quantified by the Pearson correlation coefficient R [44] (Matlab, Statistics toolbox), using only plaques spectra and core spectra. We investigated the statistical influence of cases, which contributed high amounts of plaques to the respective types (cases 7 and 9, Additional file 1: Table 1). We found that case 7 has little impact on the statistical analysis of diffuse plaques, whereas the classic cored plaques of case 9 shift the respective distributions slightly downwards, by approx. -0.16 points for protein and approx. -0.09 
points for $\beta$-sheets. Further, we found no notable alterations in the spectral data of case 7 , which had the longest post-mortem interval (10.45 h).

\section{Results}

We developed a workflow that combines FTIR, Raman, and $\mathrm{A} \beta$-IHC imaging within the same tissue thin section, thereby integrating label-free imaging with the neuropathology gold standard for plaque detection (Fig. 1). In each sample, areas of about $20 \mathrm{~mm}^{2}$ were measured by FTIR imaging. Additionally, smaller subareas of about $0.2 \mathrm{~mm}^{2}$ were imaged by Raman. Subsequently, the same tissue section was immunostained against $A \beta$ and imaged by light microscopy. By spatial overlay of vibrational and $A \beta$-IHC images, $A \beta$ plaques were clear-cut identified in FTIR and Raman images. AD neuropathology experts annotated each scanned plaque in $\mathrm{A} \beta-\mathrm{IHC}$ images to differentiate between the plaque types. We present the spectral analysis of 68 diffuse plaques [80], 32 compact plaques [16], and 60 classic cored plaques [69], measured in $20 \mu \mathrm{m}$ thick native post-mortem brain sections of $7 \mathrm{AD}$ cases. The plaques were compared to their surrounding tissue (Additional file 1: Fig. 4) and A $\beta$-negative gray matter of 3 non-demented control cases (Additional file 1: Table 1). None of the bands used here for analysis showed alterations during the measurements (Additional file 1: Fig. 1), ruling out sample degradation.

\section{FTIR imaging reveals the distribution of $B$-sheet protein in different plaque types}

We present exemplary plaques of each type in $\mathrm{A} \beta$-IHC images (Fig. 2A). Healthy control tissue is shown as a reference (Fig. $2 \mathrm{~A}_{1}$ ). The FTIR results of the same tissue areas are visualized in pseudo-color images that display protein accumulation (Fig. 2B). We observed increased protein concentrations in all plaque types, compared to control tissue. We assign this aggregated protein mostly to $A \beta$, as indicated by the respective $A \beta-\mathrm{IHC}$ images

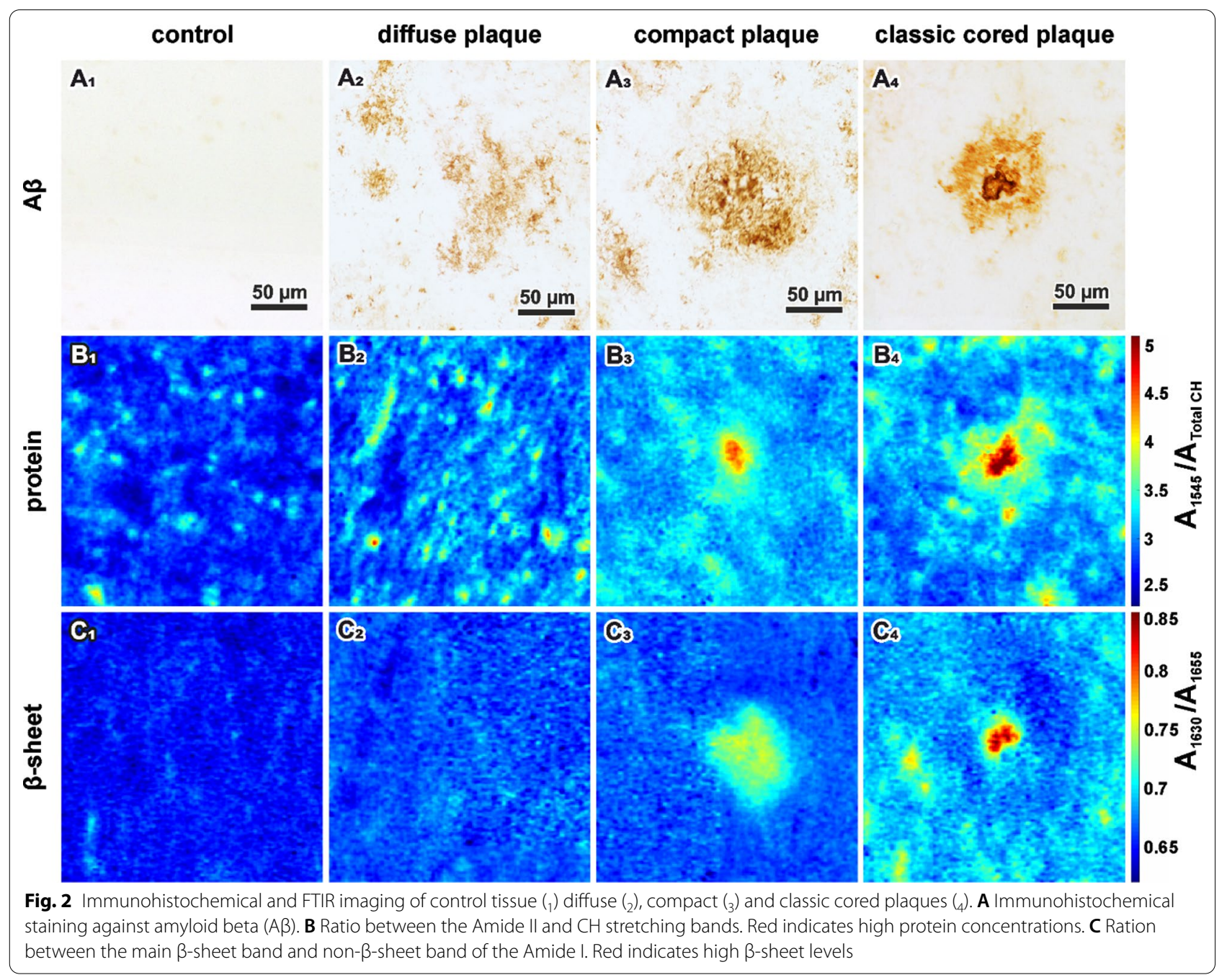


(Fig. 2A). Due to the cellular composition of brain tissue, the protein concentration in control tissue is not homogeneous (Fig. 2B $\mathrm{B}_{1}$ ). The diffuse plaque shows protein accumulations that are randomly distributed within the plaque area (Fig. $2 \mathrm{~B}_{2}$ ). In the compact plaque, protein is accumulated in the center (Fig. $2 \mathrm{~B}_{3}$ ). Overall, compact plaques displayed a wide range of protein distributions, spanning from homogeneous dispersions to centralized accumulations. Interestingly, in some compact plaques we even noted core-like protein structures (Fig. $2 \mathrm{~B}_{3}$ ), which were not visible in corresponding $\mathrm{A} \beta$-IHC images (Fig. 2 $\mathrm{A}_{3}$ ). Classic cored plaques, recognized by their typical core in $\mathrm{A} \beta$-IHC images (Fig. $2 \mathrm{~A}_{4}$ ), present in FTIR data a core with high protein content that is surrounded by a corona with less aggregated protein (Fig. $2 \mathrm{~B}_{4}$ ).

In the next step, we analyzed the secondary structure composition of $A \beta$ in the different plaque types to evaluate $\beta$-sheet levels (Fig. $2 \mathrm{C}$ ). This is elaborated from the ratio between the Amide I bands of $\beta$-sheets and non- $\beta$ sheets. Healthy gray matter shows no $\beta$-sheet aggregations (Fig. $2 \mathrm{C}_{1}$ ). In diffuse plaques, we observed slightly increased $\beta$-sheet levels (Fig. $2 \mathrm{C}_{2}$ ). The compact plaque shows increased $\beta$-sheet levels across the plaque area (Fig. $2 \mathrm{C}_{3}$ ). The classic cored plaque shows aggregated $\beta$-sheet protein, condensed in its core (Fig. $2 \mathrm{C}_{4}$ ). Interestingly, the surrounding corona displays low levels of $\beta$-sheets, similar to diffuse deposits. Two selected classic cored plaques were additionally analyzed with Raman imaging, confirming FTIR observations (Additional file 1: Fig. 6).

The characteristic core and corona structure of classic cored plaques was analyzed in more detail (Fig. 3). Plaque cores and coronas were distinguished from each other and from the surrounding tissue, based on their spectral properties, using hierarchical cluster analysis (HCA). The method is described above. We performed HCA on spectral hypercuboids of all included classic cored plaques $(n=60)$. Thereby, we separated pixel that correspond to the core of each plaque and generated core spectra of 52 out of the 60 classic cored plaques. The remaining cores were either too small to be resolved in FTIR or were discarded due to insufficient data quality. HCA results for the exemplary classic cored plaque are shown (Fig. 3A, $\mathrm{B})$. Figure $3 \mathrm{C}$ shows only the most relevant spectral range, containing the Amide I $\left(\sim 1655 \mathrm{~cm}^{-1}\right)$, Amide II $\left(\sim 1545 \mathrm{~cm}^{-1}\right)$, and the lipid-associated ester band $\left(\sim 1738 \mathrm{~cm}^{-1}\right)$. The ester band is decreased in the corona (yellow) and even more in the core (red). However, we note that the ester band does not disappear entirely, indicating a residual lipid content within the core. The structure-sensitive Amide I band of the corona is nearly identical to that of the surrounding tissue (green), indicating low $\beta$-sheet levels in the corona. In contrast,

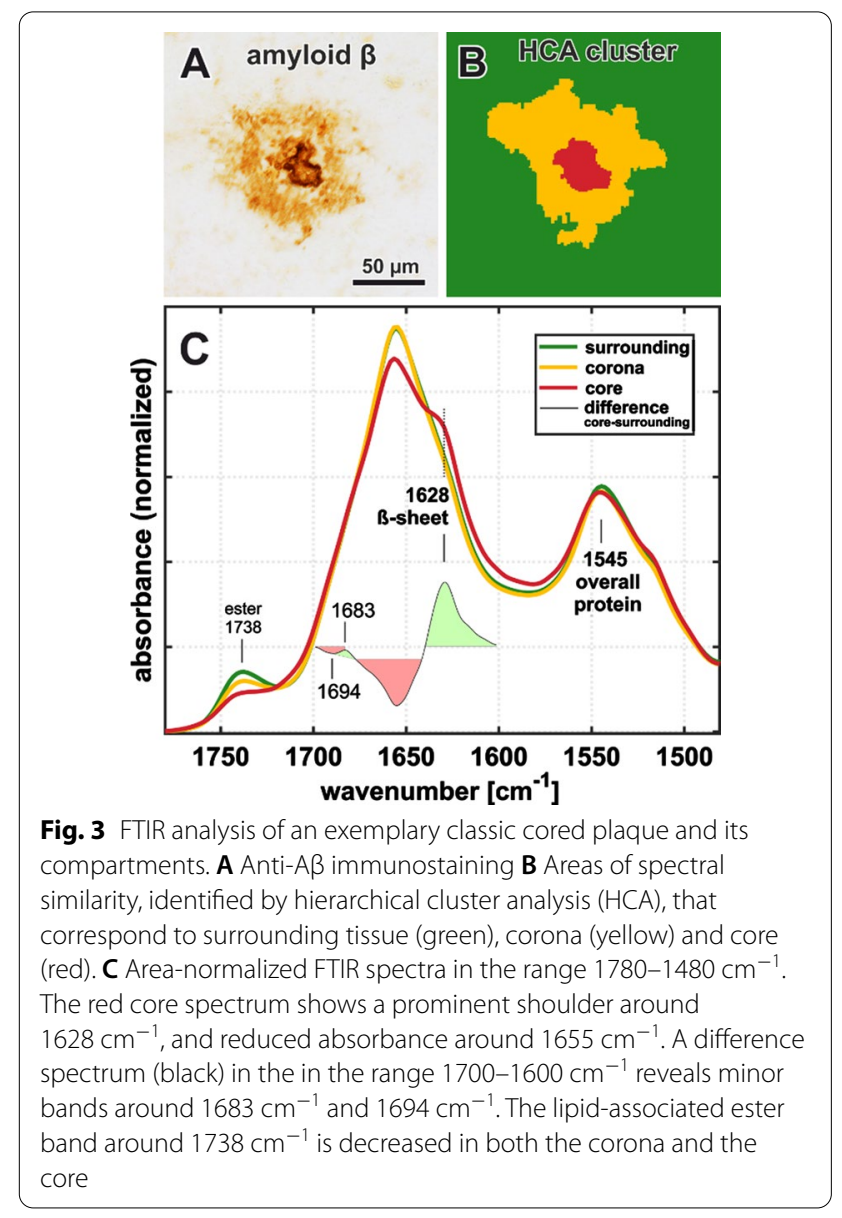

the core spectrum displays a strong shoulder around $1628 \mathrm{~cm}^{-1}$. A difference-spectrum between the core and the surrounding tissue is shown (Fig. 3C). It reveals positive bands around $1683 \mathrm{~cm}^{-1}$ and $1628 \mathrm{~cm}^{-1}$, as well as negative bands around $1694 \mathrm{~cm}^{-1}$ and $1655 \mathrm{~cm}^{-1}$.

\section{The Amide I band reveals structural properties of the $A \beta$ in plaques}

A detailed analysis of the Amide I band reveals further differences between the plaque types (Fig. 4). The previously described, increased absorbance around $1630 \mathrm{~cm}^{-1}$ manifests in a shoulder on the right side of the Amide I band (Fig. 4A). Difference spectra between plaque spectra and surrounding spectra reveal that the $1630 \mathrm{~cm}^{-1}$ band shifts to the right, alongside the proposed plaque development sequence (diffuse, compact, classic cored) (Fig. 4B). The band position reaches $1628 \mathrm{~cm}^{-1}$ in core spectra. Additionally, the right flank of the band broadens, showing increased absorbance around $1620 \mathrm{~cm}^{-1}$. The shift to lower wavenumbers is reproduced in second derivative spectra (Fig. 4C), which reveal additional bands around $1693 \mathrm{~cm}^{-1}, 1682 \mathrm{~cm}^{-1}, 1657 \mathrm{~cm}^{-1}$, 

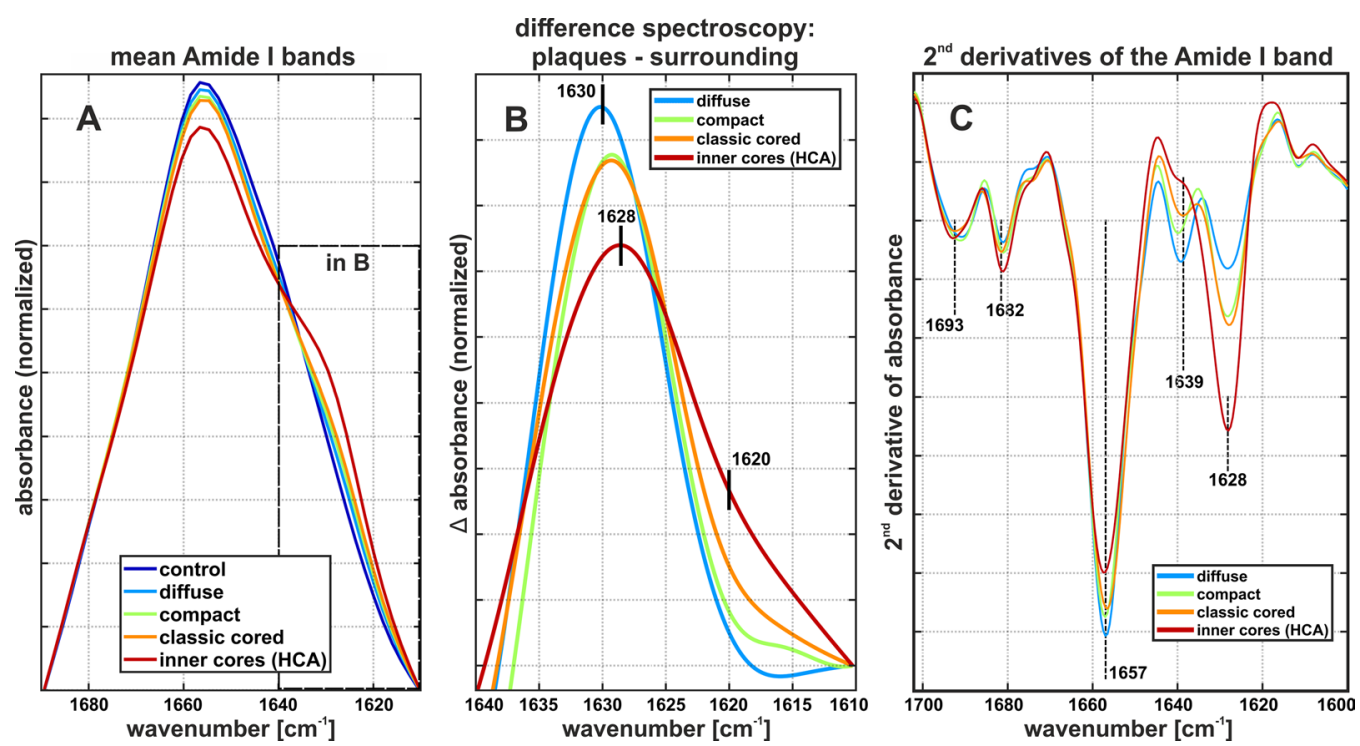

Fig. 4 Amide I band analysis. A Mean Amide I bands of all plaque spectra from each plaque type, core spectra generated by hierarchial cluster analysis (HCA), and gray matter control spectra. The shoulder around $1628 \mathrm{~cm}^{-1}$ indicates $\beta$-sheet protein. B Cutout of mean difference spectra between plaque spectra and their respective surrounding spectra. Note the shift to lower wavenumbers and the increased absorbance around $1620 \mathrm{~cm}^{-1}$. C Visualization of sub-bands of the Amide I in the region $1700-1600 \mathrm{~cm}^{-1}$. The marked local minima indicate bands that are relevant for protein secondary structure. Note the substantial increase of the band around $1628 \mathrm{~cm}^{-1}$ alongside the plaque development sequence. The band around $1693 \mathrm{~cm}^{-1}$ displays little change, whereas the band around $1682 \mathrm{~cm}^{-1}$ increases, and the bands around $1657 \mathrm{~cm}^{-1}$, and $1639 \mathrm{~cm}^{-1}$ decrease

and $1639 \mathrm{~cm}^{-1}$. The band around $1682 \mathrm{~cm}^{-1}$ is slightly increased, whereas the band around $1693 \mathrm{~cm}^{-1}$ does not change and the bands around $1657 \mathrm{~cm}^{-1}$, and $1639 \mathrm{~cm}^{-1}$ are decreased. In accordance, we observe a positive band around $1683 \mathrm{~cm}^{-1}$ and a negative band around $1694 \mathrm{~cm}^{-1}$ emerging in difference spectra (Additional file 1: Fig. 5).

Since the biochemical composition of the gray matter is inhomogeneous, especially during disease processes, it is essential to include a viable amount of plaques from a representative cohort for statistical analysis (Fig. 5). The accumulation of protein, as well as the level of $\beta$-sheets increase along the sequence from (i) gray matter control, to (ii) diffuse plaques, (iii) compact plaques, and peak in the (vi) cores of classic cored plaques (Fig. 5A, B). The $\beta$-sheet levels in diffuse plaques display some outliers (black crosses in Fig. 5B). We associate these outliers with unusually high misfolding levels with the two oldest cases in this study (cases 5 and 6, Additional file 1: Table 1). Further research will be necessary to elaborate if there is a correlation between age and $\beta$-sheet levels in diffuse plaques. Notably, we detect no significant differences between plaque spectra of compact plaques and classic cored plaques, neither regarding protein nor $\beta$-sheet levels. Remarkably, protein and $\beta$-sheet levels correlate $(R=0.73)$ in plaques (Fig. 5C). Furthermore, the height difference between the bands around $1628 \mathrm{~cm}^{-1}$ and
$1693 \mathrm{~cm}^{-1}$ increases significantly alongside the plaque development sequence (Fig. 5D), indicating an increasing dominance of the $1628 \mathrm{~cm}^{-1}$ band over the $1693 \mathrm{~cm}^{-1}$ band in mature plaques.

\section{Discussion}

We observed the accumulation of $A \beta$ with $\beta$-sheet structure in plaques, which centralizes successively alongside the proposed plaque development sequence (Fig. 2). With increasing $\mathrm{A} \beta$ density, plaque spectra show a shift of the band around $1630 \mathrm{~cm}^{-1}$ towards lower wavenumbers and a decreasing band around $1693 \mathrm{~cm}^{-1}$ (Figs. 3, 4). This behavior is consistent across cases and shows a steady transition along the proposed plaque development sequence (Fig. 5).

Several studies have already applied vibrational imaging to analyze amyloid brain deposits and thereby provided insight into protein misfolding in tissue. The tissue sections were usually not immunostained against $A \beta$, as the staining of brain tissue on non-adhesive crystal slides is difficult. Therefore, a differential analysis of $A \beta$ plaque types has not been performed yet. We have overcome this challenge with an optimized staining protocol (see methods) and now present a detailed analysis of the most common $A \beta$ plaque types. Most previous studies used mouse models of $\mathrm{AD}$, as the tissue of transgenic mice is more easily available than human tissue and usually 


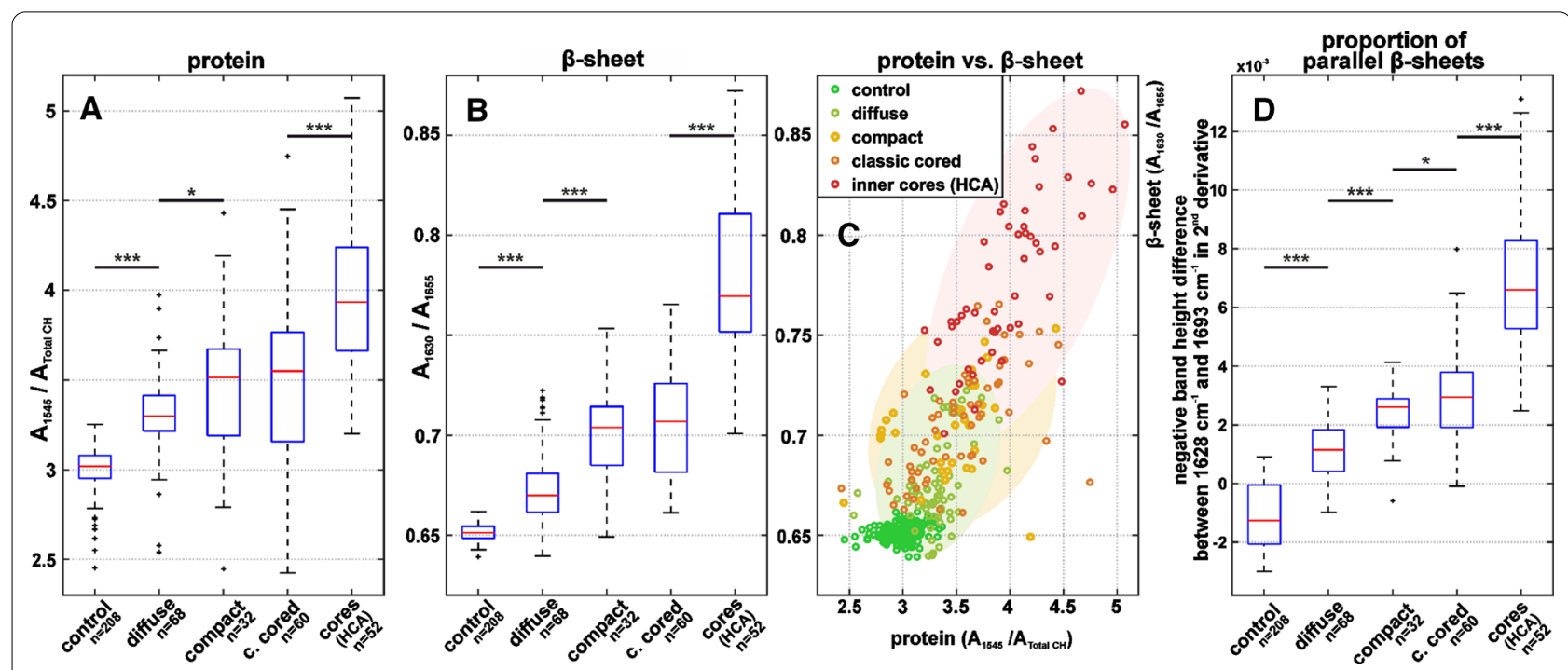

Fig. 5 Statistical analysis. The boxplots present spectroscopic ratios derived from control, plaque, and core spectra. The red bar indicates the median value, the blue boxes range between the first and third quartile. The black whiskers extend the extremes of the distribution, excluding outliers (black crosses). The significance bars announce the confidence levels. A Ratios between the Amide II band and the $\mathrm{CH}$ stretching bands, indicating protein accumulation. B Ratios between the Amide I band of $\beta$-sheets and non- $\beta$-sheet structures, indicating $\beta$-sheet levels. CThe scatterplot illustrates the correlation between protein and $\beta$-sheet levels in plaques. A successive accumulation of $\beta$-sheet protein alongside the plaque development sequence is apparent. D The negative height difference of the bands around 1628 and $1693 \mathrm{~cm}^{-1}$ in $2^{\text {nd }}$ derivative spectra, indicating increased proportions of parallel $\beta$-sheets

contains dense amyloid deposits $[24,35,41,45,58,59$, 72, 73]. Much has been elaborated about the properties of plaques this way. Surowka et al. report increased $\beta$-sheet levels in mature plaques in mice, using FTIR [73]. Fonseca et al. detect lipid-rich cell-sized depositions surrounding mature plaques using Raman microspectroscopy [24].

However, as the transferability of findings between mouse models and humans remains unclear, we investigate $A \beta$ plaques in human brain tissue here, in order to resemble the disease course and pathology in human brains. This is particularly relevant for the interplay between $A \beta$ and the various surrounding cell types, which is considered to be crucial in plaque development $[2,60,62,79,82]$. Several groups have applied vibrational imaging to human AD brain tissue before [1, 6, 22, $23,39,46,49]$. For instance, Benseny-Cases et al. report an increased $1630 \mathrm{~cm}^{-1}$ to $1650 \mathrm{~cm}^{-1}$ ratio in Thioflavin T-positive deposits from the human brain [6], which aligns well with our results on classic cored plaques (Fig. $2 \mathrm{C}_{4}$ ). Michael et al. report a shift of the Raman Amide I band towards $1666 \mathrm{~cm}^{-1}$ in amyloid deposits [49], which aligns with our observations in plaque cores (Additional file 1: Fig. 6). Klementieva et al. recently detected increased $\beta$-sheet levels in neuron models of $\mathrm{AD}$, using second derivatives of optical photothermal infrared spectra [40], which reveal a structure of the Amide I band that is similar to the here presented data
(Fig. 4C). Some of the spectroscopic studies on amyloid deposits in formaldehyde-fixated human brain tissue reported elevated lipid bands in ring-like shapes around amyloid cores, which were proposed to originate from microglia $[6,39,49]$. As we do not observe similar structures in our fresh-frozen samples, we suspect that the described lipid-like signal might be caused by the fixation procedure with formaldehyde, which is known to bind to proteins and shows lipid-like absorbance [11]. Two studies report FTIR measurements on amyloid deposits in native human brain tissue $[23,46]$. The therein-presented spectra show visibly increased absorbance around $1630 \mathrm{~cm}^{-1}$ and decreased absorbance around $1738 \mathrm{~cm}^{-1}$, which is in nice agreement with our results (Fig. 3C).

By analyzing the Amide I band in plaques, we conclude a successive accumulation of $A \beta$ with $\beta$-sheet structure from increased absorbance around $1630 \mathrm{~cm}^{-1}$ (Figs. 2, $5 \mathrm{~A}, \mathrm{~B})$ alongside the proposed plaque development sequence (diffuse, compact, classic cored). Additionally, we observe an increased peak around $1683 \mathrm{~cm}^{-1}$ (Fig. 3C and $4 \mathrm{C}$ ) that is associated with $\beta$-turns in $\beta$-sheet proteins [27], confirming the accumulation of $\beta$-sheet protein. In contrast, we do not observe increased absorbance around $1693 \mathrm{~cm}^{-1}$ (Fig. 4C), which would be expected if the deposited $A \beta$ were in an antiparallel $\beta$-sheet formation $[8,10]$. On the contrary, difference spectra reveal a decreased contribution of the $1693 \mathrm{~cm}^{-1}$ band in compact and classic cored plaques (Fig. $3 \mathrm{C}$ and Additional 
file 1: Fig. 5). We deduce that $A \beta$ adopts a parallel $\beta$-sheets structure during plaque development $[8,9]$. Further, we observe a shift of the Amide I band from around $1630 \mathrm{~cm}^{-1}$ to $1628 \mathrm{~cm}^{-1}$, accompanied by increased absorbance around $1620 \mathrm{~cm}^{-1}$ (Fig. 4B). This shift is associated with a growing number of strands in parallel $\beta$-sheets $[9,47,78]$. We conclude that increasing fractions of $A \beta$ is in extended parallel $\beta$-sheet conformation (Figs. 4, 5D). Such a shift was described for the formation of $A \beta$ fibrils $[5,54,41,63]$. The absorbance of amyloid fibrils at low wavenumbers was described in vitro $[3,81$, $83]$ as well as for $A \beta$ fibrils in cell culture $[4,41]$. In summary, we conclude the growth of parallel $\beta$-sheet fibrils alongside the plaque development sequence, in agreement with other reports $[79,82]$. The extensive knowledge about $A \beta$ fibrillation from spectroscopic studies [5, $41,54,63,64]$ allows us this careful analysis of $A \beta$ in the brain, with respect to the limitations set by the complex conditions in tissue. Thus, to the best of our knowledge, we report the first evidence of $A \beta$ fibril growth alongside the proposed plaque development sequence in the human brain.

We observed protein clusters in diffuse plaques (Fig. $2 \mathrm{~B}_{2}$ ), which might originate from parenchymal $\mathrm{A} \beta$ depositions or $A \beta$-enriched cells, which would align with descriptions of internalized $A \beta$ prior to parenchymal infestation [13, 25, 33]. Diffuse plaques displayed increased $\beta$-sheet levels compared to control tissue (Fig. 5B). The main $\beta$-sheet band is symmetric around $1630 \mathrm{~cm}^{-1}$ (Fig. 4B). The marker band $1693 \mathrm{~cm}^{-1}$ for anti-parallel $\beta$-sheets is not notably decreased in difference spectra (Additional file 1: Fig. 5). Taken together, this indicates that the $A \beta$ in diffuse plaques is primarily arranged in antiparallel $\beta$-sheets and parallel $\beta$-sheets with a low number of strands. We conclude that diffuse plaque contain mostly oligomeric and protofibrillar $A \beta$, yet in low concentrations (Fig. $6 \mathrm{~B}_{1}$ ). This aligns well with the assumption that diffuse plaques are the starting point of plaque development [34].

Compact plaques usually displayed homogenously distributed $\beta$-sheet levels, while protein levels either appeared either homogenous or centrally localized (Fig. $2 \mathrm{~B}_{3}$ ). Those centralized protein clusters were usually indistinguishable in $\mathrm{A} \beta$-IHC and $\beta$-sheet images (Fig. $2 \mathrm{~A}_{3}, \mathrm{C}_{3}$ ). FTIR imaging might be capable of detecting an emerging core in these plaques. However, the observed protein might also originate from proteins other than $A \beta$. Further investigations are necessary to clarify the origin of these observations. Furthermore, we observe a broad distribution of $\beta$-sheet levels in compact plaques (Fig. 5B). This aligns with reports, which state that not all compact plaques stain positive with Congo

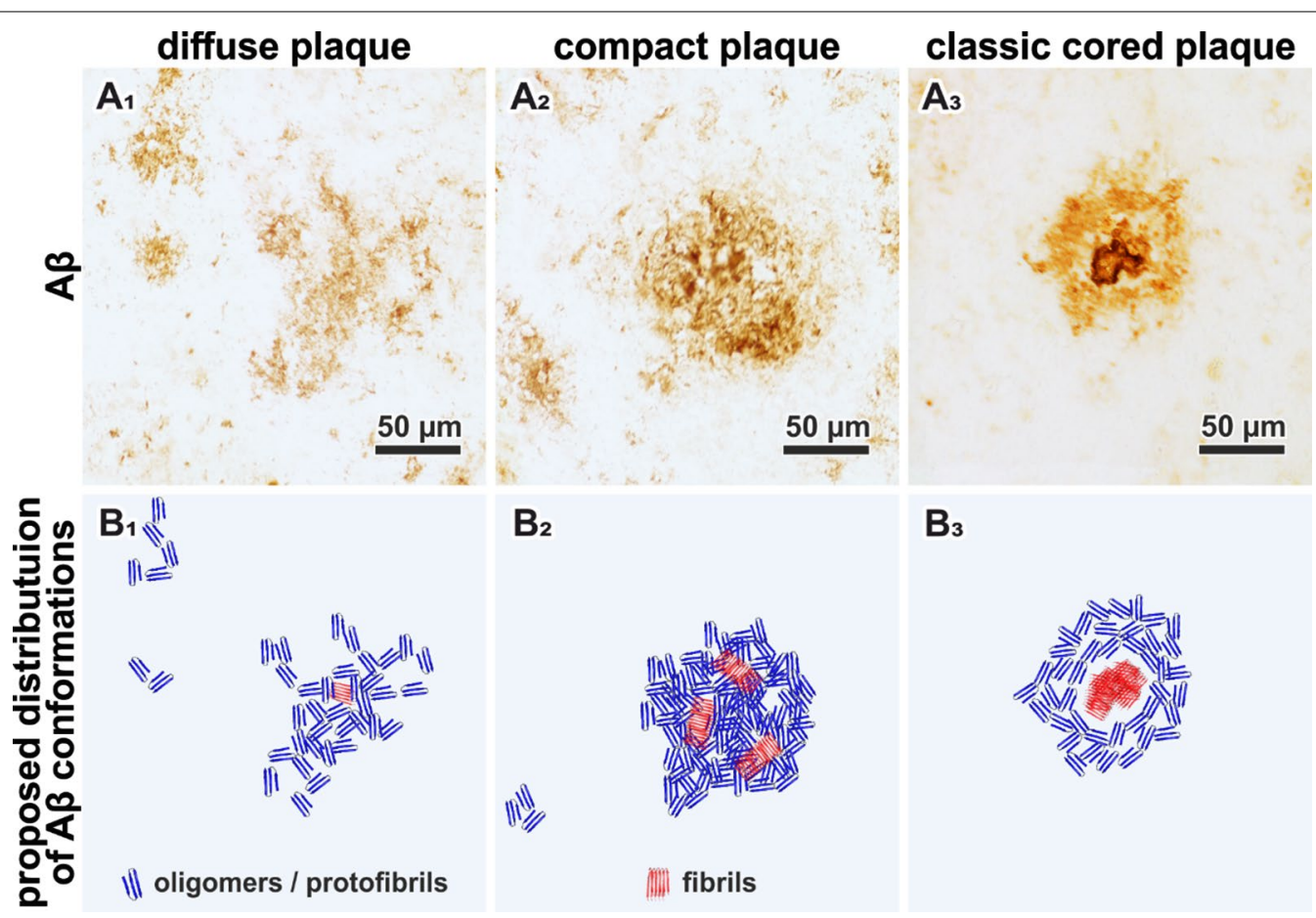

Fig. 6 Proposal of A $\mathrm{B}$ conformations in the different plaque types. A depicts the exemplary plaques from Fig. 2. B Based on our observations, we propose the depicted composition of A $\beta$ conformations in the different plaque types. The symbols are used to indicate the hypothetical location, density, and mixture of $A \beta$ conformation in a simplified fashion 
Red or Thioflavin [19, 20]. The Amide I band analysis indicates a significantly increased contribution of large parallel $\beta$-sheet structures in compact plaques (Figs. 4, $5)$. Thereby, we deduce that compact plaques contain an increased content of $\beta$-sheet $A \beta$, including varying amounts of $\mathrm{A} \beta$ fibrils (Fig. $6 \mathrm{C}_{2}$ ). Therefore, we propose that compact plaques are a heterogeneous group of intermediate states in plaque development, which cannot easily be differentiated with the most common anti-A $\beta$ staining methods.

The cores of classic cored plaques display high levels of $\beta$-sheet $\mathrm{A} \beta$ (Fig. 2). The strong band at $1628 \mathrm{~cm}^{-1}$ and the decreased band around $1693 \mathrm{~cm}^{-1}$ imply high levels of large parallel $\beta$-sheet structures. From this, we conclude an abundance of $\mathrm{A} \beta$ fibrils in the cores (Fig. $6 \mathrm{C}_{3}$ ). This is consistent with amyloid-marker-based studies $[2,15,65]$. Nevertheless, our data suggests that plaque cores are not spheres of pure $A \beta$, as their usually dense appearance in $A \beta$-IHC images may suggest. FTIR measurements detect lipids within the cores (Fig. 3C), which aligns with a previous report [46]. This may imply (i) cellular involvement, for example of infiltrating microglia or astrocytes extensions [2, 14], or the presence of processes that (ii) actively or (iii) passively integrate membranous material in the cores. Neighboring neurites may also contribute to the lipid signal, as the spatial resolution of FTIR imaging is limited. Recently, evidence for lipids and membranous material in Lewy bodies in Parkinson's disease has been reported [68]. Despite the ubiquitous abundance of lipids in the brain, this similarity of the two pathological phenomena is interesting, because it indicates cellular involvement in their respective developments; either as unintentional incorporation of e.g. cell fragments, or by cell-driven deposition [52]. Further research will be necessary to better understand the cellular involvement in the formation of $A \beta$ plaques and other neuropathologies.

In contrast to the central plaque core, we observed low levels of $\beta$-sheets in the corona of classic cored plaques (Figs. 2, 3), indicating a low content of $\beta$-sheet $\mathrm{A} \beta$ in the corona. This appears to be the reason why we do not observe significant differences between compact plaques and classic cored plaques in the statistical analysis (Fig. 5). The statistical analysis is based on the mean spectra of plaques, which include the core and corona, in case of the classic cored plaques (Additional file 1: Fig. 4). Accordingly, the relatively large corona appears to compensate for the highly fibrillar core. This implies that the $\mathrm{A} \beta$ composition in the corona is similar to that in diffuse plaques; featuring low contents of mainly oligomeric and protofibrillar $A \beta$ (Fig. $6 \mathrm{C}_{3}$ ). The substantial differences between cores and coronas may be due to the influence of inflammatory cells and the subsequent disaggregation and/or displacement of $A \beta$ fibrils. Several studies have placed activated microglia in the focus of plaque core formation [2, 60, 61, 82]. We observe the characteristic gaps that glia cells leave in $\mathrm{A} \beta-\mathrm{IHC}$ images of plaques (Fig. 2A), indicating glial involvement in the here investigated plaques. Microglia have been shown to dissolve $A \beta$ fibrils into oligomers [36]. We suspect that such $A \beta$ oligomers may be contained in the corona. Microglial involvement may also be a reason for the relatively low protein levels, which we observe in coronas (Fig. $2 \mathrm{~B}_{4}$ ), as the infiltrating microglia might displace protein with their lipid-rich cell bodies [2, 58, 82]. Additionally, several studies have found neurites and various dystrophic cell fragments in the corona $[17,19]$, which presumably contribute to $A \beta$ displacement.

Raman data of identical tissue areas validate FTIR results on classic cored plaques and reproduces the distribution of $\beta$-sheet protein in a side-by-side comparison to FTIR (Additional file 1: Fig. 6). As similar results were obtained with an independent technique, our findings are verified, confirming the reliability of our label-free approach.

In conclusion, our novel approach allowed us to track the progression of $A \beta$ fibrillation alongside the plaque development sequence, for the first time label-free, in human brain tissue thin sections. Our observations of successive accumulation and fibrillation of $\beta$-sheet structured $A \beta$ gives implications for therapeutic approaches and supports that the proposed plaque-type sequence (diffuse, compact, classic cored plaques) describes the development stages of $\mathrm{A} \beta$ plaques in $\mathrm{AD}$.

\section{Supplementary information}

Supplementary information accompanies this paper at https://doi. org/10.1186/s40478-020-01091-5.

Additional file 1. Supplementary Information. Materials and Methods Raman. Table S1. Case details. Table S2. Nomenclature. Fig. S1. Investigation of spectral alterations during long measurements. Fig. S2. Further exemplary classic cored plaque. Fig. S3. Mie correction. Fig. S4. Plaque masks. Fig. S5. Difference spectroscopy. Fig. S6. Validation with Raman.

\section{Abbreviations}

AD: Alzheimer's disease; NFT: neurofibrillary tangle; Aß: amyloid beta; FTIR: Fourier-transform infrared; APP: amyloid precursor protein; $A \beta-H C$ : anti-A $\beta$ immunohistochemistry; LPS: superior parietal lobule; FOV: field of view; ROI: region of interest; EMSC: extended multiplicative signal correction; HCA: hierarchical cluster analysis.

\section{Authors' contribution}

D.R., B.D.C.B., A.N., F.G., S.F.E., A.J.M.R. and K.G. designed research. D.R., M.S., K.K., and B.D.C.B. performed research. D.R. and B.D.C.B., analyzed data. D.R., B.D.C.B., and K.G. wrote the paper. D.R., B.D.C.B., M.S., J.J.M.H, F.H.B., A.N., S.F.E, F.G., A.J.M.R., and K.G. revised the paper. All authors read and approved the final manuscript.

\section{Acknowledgements}

The anti-A $\beta$ antibody clone IC-16 was kindly provided by Prof. Carsten Korth, Heinrich Heine Universität Düsseldorf, Germany. We would like to thank Prof. 
Wilma D.J. van de Berg for recommending the use of gelatin as tissue adhesive and we acknowledge Allert J. Jonker for technical assistance with tissue preparation.

\section{Consent for publication}

All authors have read the manuscript and indicated consent for publication.

\section{Competing interests}

The authors declare no competing financial interests.

\section{Availability of supporting data}

The data that support the findings of this study are available from the corresponding author K.G. upon reasonable request.

\section{Ethics approval and consent to participate}

Donors or their next of kin signed informed consent for the usage of brain tissue and clinical information for research purposes. The Institutional Review Board and Medical Ethical Board (METC) from the Vrije University Medical Center (VUmc) approved the procedures of the NBB.

\section{Funding}

Open Access funding enabled and organized by Projekt DEAL. This research was supported by the Protein Research Unit Ruhr within Europe (PURE), funded by the Ministry of Innovation, Science and Research (MIWF) of NorthRhine Westphalia, Germany (grant number: 233-1.08.03.03-031-68079), the Center for Protein Diagnostics (PRODI), funded by the Ministry of Culture and Science (MKW) of the State of North Rhine-Westphalia, Germany (grant number: 111.08.03.05-133974), Alzheimer Nederland (WE.15-2019-13), ZonMw (733050104), and NIH (1R01AG061775).

\begin{abstract}
Author details
${ }^{1}$ Division of Biospectroscopy, Center for Protein Diagnostics (PRODI), Ruhr University Bochum, Bochum, Germany. ${ }^{2}$ Department of Biophysics, Faculty of Biology and Biotechnology, Ruhr University Bochum, Bochum, Germany. ${ }^{3}$ Department of Pathology, Amsterdam Neuroscience, Amsterdam UMC Location VUmc, Amsterdam, The Netherlands. ${ }^{4}$ Department of Neurology, Amsterdam Neuroscience, Alzheimer Center Amsterdam, Amsterdam UMC Location VUmc, Amsterdam, The Netherlands.
\end{abstract}

Received: 8 October 2020 Accepted: 18 November 2020 Published online: 11 December 2020

\section{References}

1. Araki K, Yagi N, Ikemoto Y, Yagi H, Choong C-J, Hayakawa H et al (2015) Synchrotron FTIR micro-spectroscopy for structural analysis of Lewy bodies in the brain of Parkinson's disease patients. Sci Rep 5:17625. https:// doi.org/10.1038/srep17625

2. Arends YM, Duyckaerts C, Rozemuller JM, Eikelenboom P, Hauw JJ (2000) Microglia, amyloid and dementia in Alzheimer disease: A correlative study. Neurobiol Aging 21:39-47. https://doi.org/10.1016/S0197 $-4580(00) 00094-4$

3. Barth A (2007) Infrared spectroscopy of proteins. Biochim Biophys Acta Bioenerg 1767:1073-1101. https://doi.org/10.1016/j.bbabio.2007.06.004

4. Benseny-Cases N, Álvarez-Marimon E, Castillo-Michel H, Cotte M, Falcon C, Cladera J (2018) Synchrotron-based fourier transform infrared microspectroscopy ( $\mu \mathrm{FTIR}$ ) study on the effect of Alzheimer's A $\beta$ amorphous and fibrillar aggregates on PC12 cells. Anal Chem 90:2772-2779. https:// doi.org/10.1021/acs.analchem.7b04818

5. Benseny-Cases N, Cócera M, Cladera J (2007) Conversion of non-fibrillar $\beta$-sheet oligomers into amyloid fibrils in Alzheimer's disease amyloid peptide aggregation. Biochem Biophys Res Commun 361:916-921. https ://doi.org/10.1016/j.bbrc.2007.07.082

6. Benseny-Cases N, Klementieva O, Cotte M, Ferrer I, Cladera J (2014) Microspectroscopy ( $\mu \mathrm{FTIR}$ ) reveals co-localization of lipid oxidation and amyloid plaques in human Alzheimer disease brains. Anal Chem 86:12047-12054. https://doi.org/10.1021/ac502667b
7. Bugiani O, Giaccone G, Frangione B, Ghetti B, Tagliavini F (1989) Alzheimer patients: preamyloid deposits are more widely distributed than senile plaques throughout the central nervous system. Neurosci Lett 103:263-268. https://doi.org/10.1016/0304-3940(89)90110-9

8. Cerf E, Sarroukh R, Tamamizu-Kato S, Breydo L, Derclayes S, Dufrênes YF et al (2009) Antiparallel $\beta$-sheet: A signature structure of the oligomeric amyloid $\beta$-peptide. Biochem J 421:415-423. https://doi.org/10.1042/ BJ20090379

9. Chirgadze YN, Nevskaya NA (1976a) Infrared spectra and resonance interaction of amide-I vibration of the parallel-chain pleated sheet. Biopolymers 15:627-636. https://doi.org/10.1002/bip.1976.360150403

10. Chirgadze YN, Nevskaya NA (1976b) Infrared spectra and resonance interaction of amide-I vibration of the antiparallel-chain pleated sheet. Biopolymers 15:607-625. https://doi.org/10.1002/bip.1976.360150402

11. Craver C (1982) The Coblentz Society desk book of infrared spectra, 2nd edn. The Coblentz Society, Kirkwood

12. Cummings J, Lee G, Ritter A, Sabbagh M, Zhong K (2019) Alzheimer's disease drug development pipeline: 2019. Alzheimer's Dement Transl Res Clin Interv 5:272-293. https://doi.org/10.1016/j.trci.2019.05.008

13. D'Andrea MR (2016) Intracellular consequences of amyloid in Alzheimer's disease. Elsevier, Wilmington

14. D'Andrea MR, Cole GM, Ard MD (2004) The microglial phagocytic role with specific plaque types in the Alzheimer disease brain. Neurobiol Aging 25:675-683. https://doi.org/10.1016/j.neurobiolaging.2003.12.026

15. D'Andrea MR, Nagele RG (2010) Morphologically distinct types of amyloid plaques point the way to a better understanding of Alzheimer's disease pathogenesis. Biotech Histochem 85:133-147. https://doi. org/10.3109/10520290903389445

16. Dickson DW (1997) The pathogenesis of senile plaques. J Neuropathol Exp Neurol 56:321-339. https://doi.org/10.1097/00005072-19970 4000-00001

17. Dickson TC, Vickers JC (2001) The morphological phenotype of $\beta$-amyloid plaques and associated neuritic changes in Alzheimer's disease. Neuroscience 105:99-107. https://doi.org/10.1016/S0306-4522(01)00169-5

18. Dreissig I, Machill S, Salzer R, Krafft C (2009) Quantification of brain lipids by FTIR spectroscopy and partial least squares regression. Spectrochim Acta Part A Mol Biomol Spectrosc 71:2069-2075. https://doi. org/10.1016/j.saa.2008.08.008

19. Duyckaerts C, Delatour B, Potier M-C (2009) Classification and basic pathology of Alzheimer disease. Acta Neuropathol 118:5-36. https://doi. org/10.1007/s00401-009-0532-1

20. Duyckaerts C, Dickson D (2011) Neuropathology of Alzheimer's disease and its variants. In: Dickson DW, Weller RO (eds) Neurodegeneration: the molecular pathology of dementia and movement disorders. Wiley-Blackwell, Oxford, pp 62-91

21. El-Mashtoly SF, Petersen D, Yosef HK, Mosig A, Reinacher-Schick A, Kötting C et al (2014) Label-free imaging of drug distribution and metabolism in colon cancer cells by Raman microscopy. Analyst 139:1155. https://doi. org/10.1039/c3an01993d

22. Fabian H, Choo LPI, Szendrei Gl, Jackson M, Halliday WC, Otvos L et al (1993) Infrared spectroscopic characterization of Alzheimer plaques. Appl Spectrosc 47:1513-1518. https://doi.org/10.1366/0003702934067469

23. Findlay CR, Wiens R, Rak M, Sedlmair J, Hirschmugl CJ, Morrison J et al (2015) Rapid biodiagnostic ex vivo imaging at $1 \mu \mathrm{m}$ pixel resolution with thermal source FTIR FPA. Analyst 140:2493-2503

24. Fonseca EA, Lafetá L, Cunha R, Miranda H, Campos J, Medeiros HG et al (2019) A fingerprint of amyloid plaques in a bitransgenic animal model of Alzheimer's disease obtained by statistical unmixing analysis of hyperspectral Raman data. Analyst 144:7049-7056. https://doi.org/10.1039/ C9AN01631G

25. Friedrich RP, Tepper K, Ronicke R, Soom M, Westermann M, Reymann K et al (2010) Mechanism of amyloid plaque formation suggests an intracellular basis of A pathogenicity. Proc Natl Acad Sci 107:1942-1947. https ://doi.org/10.1073/pnas.0904532106

26. Garczarek F, Gerwert K (2006) Functional waters in intraprotein proton transfer monitored by FTIR difference spectroscopy. Nature 439:109-112. https://doi.org/10.1038/nature04231

27. Goormaghtigh E, Cabiaux V, Ruysschaert JM (1994) Determination of soluble and membrane protein structure by Fourier transform infrared spectroscopy. II. Experimental aspects, side chain 
structure, and H/D exchange. Subcell Biochem 23:363-403. https://doi. org/10.1007/978-1-4615-1863-1_9

28. Goormaghtigh E, Derenne A, Bénard A, Gasper R, Raussens V (2010) Data processing in FTIR imaging of cells: towards protein secondary structure imaging. Spectroscopy 24:51-54. https://doi.org/10.3233/SPE-2010-0403

29. Goormaghtigh E, Ruysschaert J-M, Raussens V (2006) Evaluation of the information content in infrared spectra for protein secondary structure determination. Biophys J 90:2946-2957. https://doi.org/10.1529/bioph ysj.105.072017

30. Großerueschkamp F, Bracht T, Diehl HC, Kuepper C, Ahrens M, Kallenbach-Thieltges A et al (2017) Spatial and molecular resolution of diffuse malignant mesothelioma heterogeneity by integrating label-free FTIR imaging, laser capture microdissection and proteomics. Sci Rep 7:44829. https://doi.org/10.1038/srep44829

31. Güldenhaupt J, Adigüzel Y, Kuhlmann J, Waldmann H, Kötting C, Gerwert K (2008) Secondary structure of lipidated Ras bound to a lipid bilayer. FEBS J 275:5910-5918. https://doi.org/10.1111/j.1742-4658.2008.06720.x

32. Haass C, Selkoe DJ (2007) Soluble protein oligomers in neurodegeneration: lessons from the Alzheimer's amyloid $\beta$-peptide. Nat Rev Mol Cell Biol 8:101-112

33. Head E, Garzon-Rodriguez W, Johnson JK, Lott IT, Cotman CW, Glabe C (2001) Oxidation of $A \beta$ and plaque biogenesis in Alzheimer's disease and Down syndrome. Neurobiol Dis 8:792-806. https://doi.org/10.1006/ nbdi.2001.0431

34. Ikeda S-I, Yanagisawa N, Allsop D, Glenner GG (1990) Early senile plaques in Alzheimer's disease demonstrated by histochemistry, immunocytochemistry, and electron microscopy. Hum Pathol 21:1221-1226. https:// doi.org/10.1016/S0046-8177(06)80034-1

35. Ji M, Arbel M, Zhang L, Freudiger CW, Hou SS, Lin D et al (2018) Labelfree imaging of amyloid plaques in Alzheimer's disease with stimulated raman scattering microscopy. Sci Adv 4:1-9. https://doi.org/10.1126/ sciadv.aat7715

36. Joshi P, Turola E, Ruiz A, Bergami A, Libera DD, Benussi L et al (2014) Microglia convert aggregated amyloid- $\beta$ into neurotoxic forms through the shedding of microvesicles. Cell Death Differ 21:582-593. https://doi. org/10.1038/cdd.2013.180

37. Kauffmann E, Austin R, Gerwert K (2001) Probing protein folding with time-resolved FTIR spectroscopy — novel techniques for the investigation of changes in protein conformation. BIF Future 16:152-158

38. Kirschner DA, Inouye H, Duffy LK, Sinclair A, Lind M, Selkoe DJ (1987) Synthetic peptide homologous to beta protein from Alzheimer disease forms amyloid-like fibrils in vitro. Proc Natl Acad Sci USA 84:6953-6957. https://doi.org/10.1073/pnas.84.19.6953

39. Kiskis J, Fink H, Nyberg L, Thyr J, Li JY, Enejder A (2015) Plaque-associated lipids in Alzheimer's diseased brain tissue visualized by nonlinear microscopy. Sci Rep 5:1-9. https://doi.org/10.1038/srep13489

40. Klementieva O, Sandt C, Martinsson I, Kansiz M, Gouras GK, Borondics F (2020) Super-resolution infrared imaging of polymorphic amyloid aggregates directly in neurons. Adv Sci. https://doi.org/10.1002/advs.20190 3004

41. Klementieva O, Willén K, Martinsson I, Israelsson B, Engdahl A, Cladera J et al (2017) Pre-plaque conformational changes in Alzheimer's diseaselinked A $\beta$ and APP. Nat Commun 8:14726. https://doi.org/10.1038/ ncomms 14726

42. Konevskikh T, Lukacs R, Kohler A (2018) An improved algorithm for fast resonant Mie scatter correction of infrared spectra of cells and tissues. J Biophotonics 11:1-10. https://doi.org/10.1002/jbio.201600307

43. Krafft C, Neudert L, Simat T, Salzer R (2005) Near infrared Raman spectra of human brain lipids. Spectrochim Acta Part A Mol Biomol Spectrosc 61:1529-1535. https://doi.org/10.1016/j.saa.2004.11.017

44. Lee Rodgers J, Nicewander WA (1988) thirteen ways to look at the correlation coefficient. Am Stat 42:59-66. https://doi.org/10.1080/00031 305.1988.10475524

45. Leskovjan AC, Lanzirotti A, Miller LM (2009) Amyloid plaques in PSAPP mice bind less metal than plaques in human Alzheimer's disease. Neuroimage 47:1215-1220. https://doi.org/10.1016/j.neuroimage.2009.05.063

46. Liao CR, Rak M, Lund J, Unger M, Platt E, Albensi BC et al (2013) Synchrotron FTIR reveals lipid around and within amyloid plaques in transgenic mice and Alzheimer's disease brain. Analyst 138:3991-3997. https://doi. org/10.1039/c3an00295k
47. Lomont JP, Ostrander JS, Ho J-J, Petti MK, Zanni MT (2017) Not all $\beta$-sheets are the same: amyloid infrared spectra, transition dipole strengths, and couplings investigated by 2D IR spectroscopy. J Phys Chem B 121:89358945. https://doi.org/10.1021/acs.jpcb.7b06826

48. McGeer PL, Itagaki S, Tago H, McGeer EG (1987) Reactive microglia in patients with senile dementia of the Alzheimer type are positive for the histocompatibility glycoprotein HLA-DR. Neurosci Lett 79:195-200. https ://doi.org/10.1016/0304-3940(87)90696-3

49. Michael R, Lenferink A, Vrensen GFJM, Gelpi E, Barraquer RI, Otto C (2017) Hyperspectral Raman imaging of neuritic plaques and neurofibrillary tangles in brain tissue from Alzheimer's disease patients. Sci Rep 7:1-11. https://doi.org/10.1038/s41598-017-16002-3

50. Michaels TCT, Šarić A, Curk S, Bernfur K, Arosio P, Meisl G et al (2020) Dynamics of oligomer populations formed during the aggregation of Alzheimer's Aß42 peptide. Nat Chem 12:445-451. https://doi. org/10.1038/s41557-020-0452-1

51. Montine TJ, Phelps CH, Beach TG, Bigio EH, Cairns NJ, Dickson DW et al (2012) National institute on aging-Alzheimer's association guidelines for the neuropathologic assessment of Alzheimer's disease: a practical approach. Acta Neuropathol 123:1-11. https://doi.org/10.1007/s0040 1-011-0910-3

52. Moors TE, Maat CA, Niedieker D, Mona D, Petersen D, Timmermans-Huisman E, et al. (2018) Subcellular orchestration of alpha-synuclein variants in Parkinson's disease brains revealed by 3D multicolor STED microscopy. bioRxiv 470476. https://doi.org/10.1101/470476

53. Morell P, Quarles R (1999) Characteristic composition of myelin. In: Siegel G, Agranoff R, Albers R (eds) Basic neurochemistry: molecular, cellular and medical aspects, 6th edn. Lippincott-Raven, Philadelphia

54. Nabers A, Ollesch J, Schartner J, Kötting C, Genius J, Hafermann H et al (2016) Amyloid- $\beta$-secondary structure distribution in cerebrospinal fluid and blood measured by an immuno-infrared-sensor: a biomarker candidate for Alzheimer's disease. Anal Chem 88:2755-2762. https://doi. org/10.1021/acs.analchem.5b04286

55. Nelson PT, Alafuzoff I, Bigio EH, Bouras C, Braak H, Cairns NJ et al (2012) Correlation of alzheimer disease neuropathologic changes with cognitive status: a review of the literature. J Neuropathol Exp Neurol 71:362-381. https://doi.org/10.1097/NEN.0b013e31825018f7

56. O'Brien JS, Sampson EL (1965) Lipid composition of the normal human brain: gray matter, white matter, and myelin. J Lipid Res 6:537-544

57. Otsu N (1979) A threshold selection method from gray-level histograms. IEEE Trans Syst Man Cybern 9:62-66. https://doi.org/10.1109/ TSMC.1979.4310076

58. Palombo F, Tamagnini F, Jeynes JCG, Mattana S, Swift I, Nallala J et al (2018) Detection of A $\beta$ plaque-associated astrogliosis in Alzheimer's disease brain by spectroscopic imaging and immunohistochemistry. Analyst 143:850-857. https://doi.org/10.1039/C7AN01747B

59. Rak M, Del Bigio MR, Mai S, Westaway D, Gough KM (2007) Dense-core and diffuse A $\beta$ plaques in TgCRND8 mice studied with synchrotron FTIR microspectroscopy. Biopolymers 87:207-217. https://doi.org/10.1002/ bip. 20820

60. Rozemuller AJM, Jansen C, Carrano A, Van Haastert ES, Hondius D, Van Der Vies SM et al (2012) Neuroinflammation and common mechanism in Alzheimer's disease and prion amyloidosis: Amyloid-associated proteins, neuroinflammation and neurofibrillary degeneration. Neurodegener Dis 10:301-304. https://doi.org/10.1159/000335380

61. Rozemuller JM, Eikelenboom P, Stam FC (1986) Role of microglia in plaque formation in senile dementia of the Alzheimer type - An immunohistochemical study. Virchows Arch B Cell Pathol Incl Mol Pathol 51:247-254. https://doi.org/10.1007/BF02899034

62. Rozemuller JM, Eikelenboom P, Stam FC, Beyreuther K, Masters CL (1989) A4 protein in Alzheimer's disease: primary and secondary cellular events in extracellular amyloid deposition. J Neuropathol Exp Neurol 48:674691. https://doi.org/10.1097/00005072-198911000-00009

63. Sarroukh R, Cerf E, Derclaye S, Dufrêne YF, Goormaghtigh E, Ruysschaert JM et al (2011) Transformation of amyloid $\beta(1-40)$ oligomers into fibrils is characterized by a major change in secondary structure. Cell Mol Life Sci 68:1429-1438. https://doi.org/10.1007/s00018-010-0529-x

64. Sarroukh R, Goormaghtigh E, Ruysschaert JM, Raussens V (2013) ATR-FTIR: A "rejuvenated" tool to investigate amyloid proteins. Biochim Biophys Acta Biomembr 1828:2328-2338. https://doi.org/10.1016/j.bbame m.2013.04.012 
65. Schmidt ML, Robinson KA, Lee VMY, Trojanowski JQ (1995) Chemical and immunological heterogeneity of fibrillar amyloid in plaques of Alzheimer's disease and Down's syndrome brains revealed by confocal microscopy. Am J Pathol 147:503-515

66. Selkoe DJ (1989) Amyloid $\beta$ protein precursor and the pathogenesis of Alzheimer's disease. Cell 58:611-612. https://doi.org/10.1016/00928674(89)90093-7

67. Sevigny J, Chiao P, Bussière T, Weinreb PH, Williams L, Maier M et al (2016) The antibody aducanumab reduces $A \beta$ plaques in Alzheimer's disease. Nature 537:50-56. https://doi.org/10.1038/nature19323

68. Shahmoradian SH, Lewis AJ, Genoud C, Hench J, Moors TE, Navarro PP et al (2019) Lewy pathology in Parkinson's disease consists of crowded organelles and lipid membranes. Nat Neurosci 22:1099-1109. https://doi. org/10.1038/s41593-019-0423-2

69. Sheng JG, Zhou XQ, Mrak RE, Griffin WST (1998) Progressive neuronal injury associated with amyloid plaque formation in Alzheimer disease. J Neuropathol Exp Neurol 57:714-717. https://doi.org/10.1097/00005072199807000-00008

70. Solheim JH, Gunko E, Petersen D, Großerüschkamp F, Gerwert K, Kohler A (2019) An open-source code for Mie extinction extended multiplicative signal correction for infrared microscopy spectra of cells and tissues. J Biophotonics. https://doi.org/10.1002/jbio.201800415

71. Student (W.S. Gosset) (1908) The probable error of a mean. Biometrika 6:1. https://doi.org/10.2307/2331554

72. Summers KL, Fimognari N, Hollings A, Kiernan M, Lam V, Tidy RJ et al (2017) A multimodal spectroscopic imaging method to characterize the metal and macromolecular content of proteinaceous aggregates ("amyloid plaques"). Biochemistry 56:4107-4116. https://doi.org/10.1021/ acs.biochem.7b00262

73. Surowka AD, Pilling M, Henderson A, Boutin H, Christie L, SzczerbowskaBoruchowska M et al (2017) FTIR imaging of the molecular burden around A $\beta$ deposits in an early-stage 3-Tg-APP-PSP1-TAU mouse model of Alzheimer's disease. Analyst 142:156-168. https://doi.org/10.1039/ c6an01797e

74. T. Griffin WS, Sheng JG, Roberts GW, Mrak RE (1995) Interleukin-1 expression in different plaque types in Alzheimer's disease. J Neuropathol Exp Neurol 54:276-281. https://doi.org/10.1097/00005072-199503000-00014

75. Tagliavini F, Giaccone G, Frangione B, Bugiani O (1988) Preamyloid deposits in the cerebral cortex of patients with Alzheimer's disease and nondemented individuals. Neurosci Lett 93:191-196. https://doi. org/10.1016/0304-3940(88)90080-8
76. Thal DR (2006) The development of amyloid beta protein deposits in the aged brain. Sci Aging Knowl Environ. https://doi.org/10.1126/sagek e.2006.6.re1

77. Tolar M, Abushakra S, Hey JA, Porsteinsson A, Sabbagh M (2020) Aducanumab, gantenerumab, BAN2401, and ALZ-801 - the first wave of amyloid-targeting drugs for Alzheimer's disease with potential for near term approval. Alzheimer's Res Ther 12:1-10. https://doi.org/10.1186/ s13195-020-00663-W

78. Welch WRW, Kubelka J, Keiderling TA (2013) Infrared, vibrational circular dichroism, and raman spectral simulations for $\beta$-sheet structures with various isotopic labels, interstrand, and stacking arrangements using density functional theory. J Phys Chem B 117:10343-10358. https://doi. org/10.1021/jp4056126

79. Xie H, Hou S, Jiang J, Sekutowicz M, Kelly J, Bacskai BJ (2013) Rapid cell death is preceded by amyloid plaque-mediated oxidative stress. Proc Natl Acad Sci U S A 110:7904-7909. https://doi.org/10.1073/pnas.1217938110

80. Yamaguchi H, Hirai S, Morimatsu M, Shoji M, Harigaya Y (1988) Diffuse type of senile plaques in the brains of Alzheimer-type dementia. Acta Neuropathol 77:113-119. https://doi.org/10.1007/BF00687420

81. Yamaguchi Kl, Takahashi S, Kawai T, Naiki H, Goto Y (2005) Seedingdependent propagation and maturation of amyloid fibril conformation. J Mol Biol 352:952-960. https://doi.org/10.1016/j.jmb.2005.07.061

82. Yuan P, Condello C, Keene CD, Wang Y, Bird TD, Paul SM et al (2016) TREM2 haplodeficiency in mice and humans impairs the microglia barrier function leading to decreased amyloid compaction and severe axonal dystrophy. Neuron 90:724-739. https://doi.org/10.1016/j.neuron.2016.05.003

83. Zandomeneghi G, Krebs MRH, McCammon MG, Fändrich M (2004) FTIR reveals structural differences between native beta-sheet proteins and amyloid fibrils. Protein Sci 13:3314-3321. https://doi.org/10.1110/ ps.041024904

\section{Publisher's Note}

Springer Nature remains neutral with regard to jurisdictional claims in published maps and institutional affiliations.
Ready to submit your research? Choose BMC and benefit from:

- fast, convenient online submission

- thorough peer review by experienced researchers in your field

- rapid publication on acceptance

- support for research data, including large and complex data types

- gold Open Access which fosters wider collaboration and increased citations

- maximum visibility for your research: over 100M website views per year

At BMC, research is always in progress.

Learn more biomedcentral.com/submissions 